\title{
Clear cell myoepithelioma of the hard palate
}

\author{
Arsheed Hussain Hakeem, ${ }^{a}$ Biswajyoti Hazarika, ${ }^{\mathrm{b}}$ Imtiyaz Hussain Hakeem ${ }^{\mathrm{c}}$ \\ From the aSurgical Oncology, Prince Aly Khan Hospital, Nesbit Road, Mazagaon, Mumbai, Maharashtra, India, bSurgical Oncology, Max Cancer \\ Centre, Saket, New Delhi, India, Internal Medicine, Florida Hospital Medical Center, Winter Park Orlando, Florida, USA \\ Correspondence: Arsheed Hussain Hakeem, MD · Nesbit Road, Mazagaon, Mumbai 400010 Maharashtra, India · T: +91-9920226332 \\ F: (91-22) 25763344/3311·drahhakim@gmail.com \\ Ann Saudi Med 2013; 33(5): 492-494
}

DOI: $10.5144 / 0256-4947.2013 .492$

\begin{abstract}
Clear cell myoepithelioma arising from the minor salivary glands of hard palate is a rare entity. Most of the cases of palatal myoepitheliomas reported so far are either plasmacytoid or spindle cell type. Our literature search revealed only one case report of clear cell myoepithelioma of the palate. We report a case in a 21-year-old female who presented to us with a non-ulcerating, painless firm swelling of the left side of the hard palate. The tumor was excised with a healthy rim of surrounding tissue. Immunohistochemistry was performed on formalin-fixed and paraffin-embedded tissue with a panel of immunohistochemical markers. Tumor cells showed positivity for S100, cytokeratin and Muscle specific actin. Histological and immunohistochemical analyses revealed the tumor to be a myoepithelioma of the clear cell variety.
\end{abstract}

$\mathrm{M}$ yoepitheliomas are very rare tumurs of the salivary glands constituting less than $1.5 \%$ of all salivary gland tumors. ${ }^{1}$ The most common site of occurrence is the parotid gland..$^{1-3}$ Although, clear cell myoepitheliomas have been reported at the other sites, most of the cases of palatal myoepitheliomas reported are either of the plasmacytoid or spindle cell type. ${ }^{4}$ A review of published reports revealed only one case of clear cell myoepithelioma of the hard palate reported by Agarwal et al. ${ }^{5}$ The extreme rarity of clear cell myoepithelioma of the hard palate prompted us to report this case with the objective of contributing to a better understanding of this neoplasm. We discuss the clinical, radiological and pathological characteristics.

\section{CASE}

A 21-year-old female was referred to the Head and Neck Unit at Prince Aly Khan hospital, Department of Surgical Oncology, with recurrent painless swelling of the hard palate. She had undergone excision of the a similar swelling in the same region 4 months previously in another facility. Histopathological analysis of the previous surgical specimen showed it to be clear cell myoepithelioma. There was history of a progressive but slow increase in the size of this recurrent swelling. On intraoral examination there was smooth, fleshy, firm mass on left side of the hard palate approximately $3 \times 3$ $\mathrm{cm}$ in size (Figure 1).
CT scan of the paranasal sinuses showed a well defined lobulated enhancing soft tissue mass, $3.4 \times 2.5 \mathrm{~cm}$ in the transverse plane causing expansion of the left maxillary sinus. Erosion of the medial wall and floor of the maxillary sinus, including a portion of the maxillary alveolar process (in the molar region), was also noted. Mild focal erosion of the posterior wall of the left maxillary sinus was also seen without extension of the soft tissue into the masticator space. Widening of the pterygo-palatine fissure was also noted on CT scan with the presence of enhancing soft tissue within it (Figure 2).

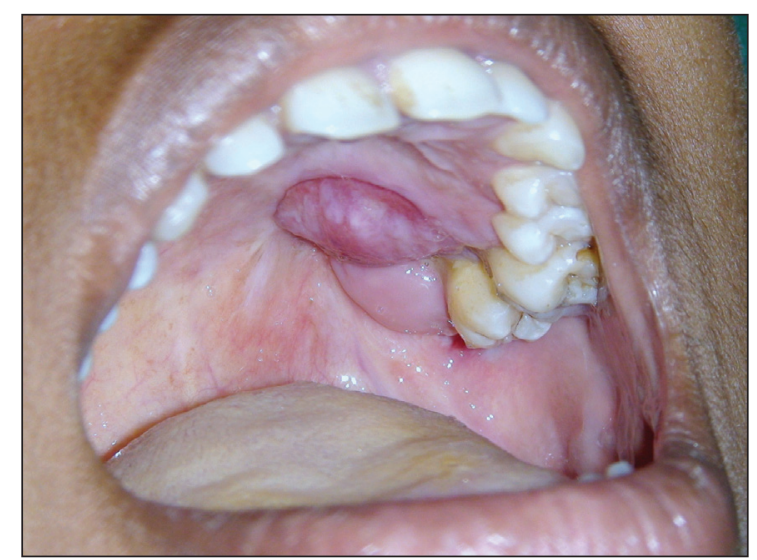

Figure 1. Clinical picture showing the smooth swelling on the left side of the hard palate. 


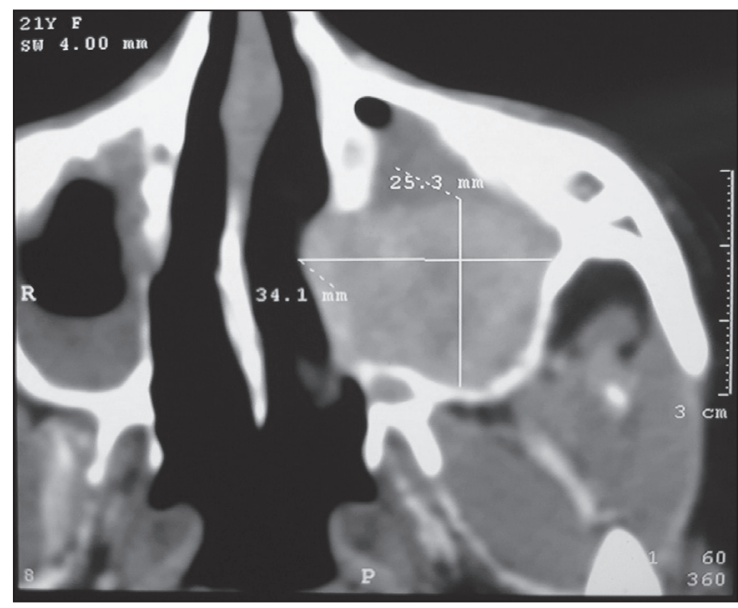

Figure 2. CT scan axial view showing the well-defined lobulated mass eroding the palate with extension into the maxillary antrum.

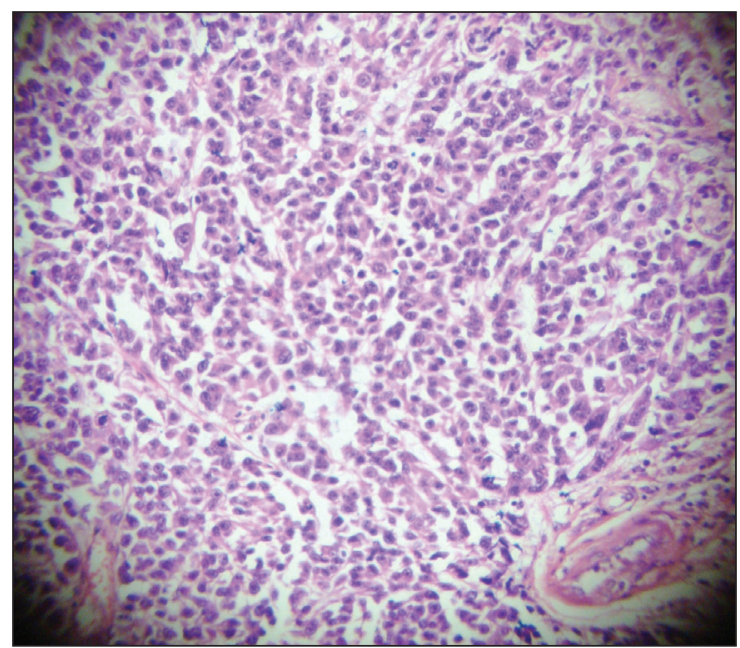

Figure 3. Photomicrograph under low power showing sheets and cords of ovoid to spindle component with moderate amount of pale to eosinophilic cytoplasm (hematoxylin-eosin stain $\times 100$ ).

With these observations and previous histopathology, a diagnosis of recurrent/residual clear cell myoepithelioma was made.

An enbloc infrastructure maxillectomy was done with adequate margins. Histpathological examination of the surgical specimen showed grossly infiltrative fleshy white circumscribed mass measuring $3.8 \times 3.7 \times 2$ $\mathrm{cm}$ with adequate cut margins. The overlying mucosa was opaque, white and smooth. The tumor was composed of large polyhedral cells with clear eosinophilic cytoplasm and these cells were arranged in closely packed interlacing bundles. The nuclei were round to

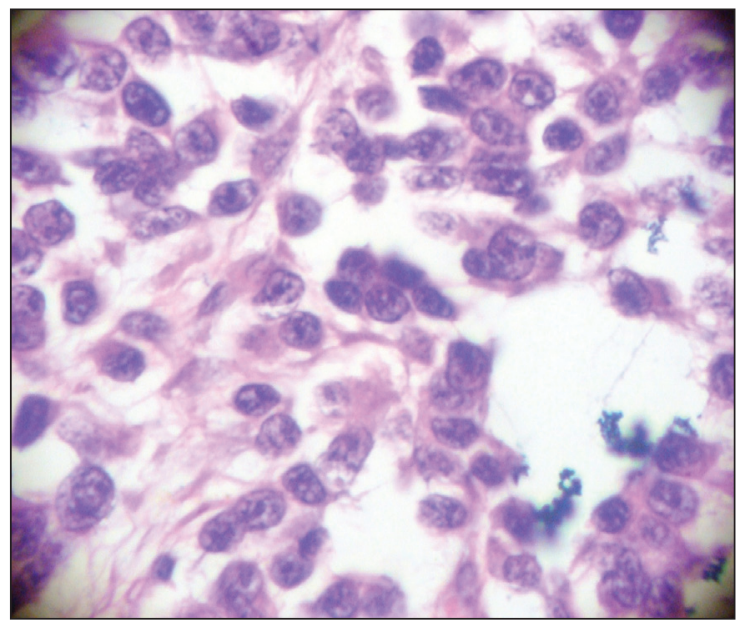

Figure 4. Photomicrograph under high power showing ovoid to spindle cells with uniform, mildly hyperchromatic nuclei and inconspicuous nucleolei (hematoxylin-eosin stain $\times 100$ ).

Table 1. Reported cases of myoepithelioma of minor salivary gland tumor of palate.

\begin{tabular}{|c|c|c|c|}
\hline Report & Age/Sex & Site & Cell type \\
\hline Kahn and Schoub ${ }^{9}$ & $17 / \mathrm{F}$ & Hard palate & Plasmacytoid \\
\hline Luna et $a^{10}$ & $30 / F$ & Hard palate & Spindle \\
\hline $\begin{array}{l}\text { Sciubba and } \\
\text { Goldstein } 1\end{array}$ & $22 / M$ & palate & Plasmacytoid \\
\hline Nesland et al ${ }^{11}$ & $18 / \mathrm{F}$ & Soft palate & Plasmacytoid \\
\hline Barnes et al ${ }^{6}$ & $24 / \mathrm{F}$ & Hard palate & Plasmacytoid \\
\hline Enomoto et al ${ }^{12}$ & $57 / \mathrm{F}$ & Soft palate & Plasmacytoid \\
\hline Ellyn and Gnepp $p^{13}$ & $8 / F$ & Soft palate & Plasmacytoid \\
\hline Kawabe et al ${ }^{14}$ & $53 / M$ & Soft palate & Plasmacytoid \\
\hline Stromeyer et al ${ }^{15}$ & $14 / M$ & Anterior maxilla & $\begin{array}{c}\text { Cytological } \\
\text { pleomorphism }\end{array}$ \\
\hline Harusachi et al ${ }^{16}$ & $42 / \mathrm{F}$ & Hard palate & Plasmacytoid \\
\hline Agarwal et al ${ }^{5}$ & $40 / \mathrm{F}$ & Hard palate & Clear cell type \\
\hline Rastogi et al ${ }^{17}$ & $33 / \mathrm{M}$ & Hard palate & Plamacytoid \\
\hline Lins JE et a $\left.\right|^{18}$ & $8 / F$ & Soft palate & Plasmacytoid \\
\hline Lopez Jl et al ${ }^{19}$ & $46 / M$ & Soft palate & Plasmacytoid \\
\hline Acikalin MF et a ${ }^{20}$ & $32 / \mathrm{M}$ & Soft palate & Plasmacytoid \\
\hline Zelaya et a ${ }^{21}$ & $28 / \mathrm{F}$ & Hard palate & Plasmacytoid \\
\hline Kanazawa $\mathrm{H}$ et al ${ }^{4}$ & $42 / \mathrm{F}$ & Hard palate & Plasmacytoid \\
\hline Katsuyama $\mathrm{E}$ et al ${ }^{22}$ & $67 / \mathrm{F}$ & Soft palate & Plasmacytoid \\
\hline Nwoku et a ${ }^{23}$ & $11 / M$ & Palate & Plasmacytoid \\
\hline Present case & $21 / \mathrm{F}$ & Hard palate & Clear cell type \\
\hline
\end{tabular}


oval, eccentrically placed and were vesicular with small nucleoli (Figures 3, 4).

Immunohistochemically, the clear cells were immunoreactive for cytokeratin, S-100 and muscle-specific actin (MSA). A diagnosis of clear cell type myoepithelioma of minor salivary gland origin was made on microscopy and tumor was invasive in nature. The postoperative period was uneventful. Since she had a recurrence and the tumor was invasive in nature, adjuvant treatment of postoperative adjuvant radiotherapy was also given to the primary site. After 3 years of follow up she was free of disease without any signs of recurrence.

\section{DISCUSSION}

Myoepitheliomas are rare benign tumors, with the parotid gland and palate accounting for three-fourths of all cases. ${ }^{6}$ The plasmacytoid variant is usually seen on the palate in slightly younger individuals, while the spindle cell type tends to occur in the parotid gland of older individuals. ${ }^{7,8}$ Clear cell tumors of the salivary glands are almost invariably malignant in nature, with rare exceptions in the form of myoepitheliomas and oncocytomas. ${ }^{8}$ Our literature search revealed only one case of clear cell myoepithelioma of the hard palate reported by Agarwal et al. ${ }^{5}$ In our review, 20 cases of ultrastructurally or immunohistochemically confirmed myoepithelioma of the palatal minor salivary gland were found (Table 1). Of the 20 cases of palatal myoepitheliomas reported, 17 cases were of the plasmacytoid cell type, two were of the clear cell type, one belonged to the spindle cell variety and one was of mixed cellularity.

Electron microscopic and immunohistochemical examinations are useful for accurate identification and characterization of myoepithelial cells. Immunohistochemically, a large number of markers have been used for establishing the diagnosis of myoepitheliomas. The myoepithelial cells are usually found to be immunoreactive to $\mathrm{S}-100$, actin and prekeratin, and are nonreactive to desmin and EMA. Other markers that have been used in some reports are CEA, secretory piece, high molecular weight keratin, cytokeratin and factor VIII antigen. ${ }^{4}$ The reactivity to MSA and vimentin has been reported variably in different reports ${ }^{6,10-12}$ In our patient, the tumor cells were found to be immunoreactive to MSA, S-100 and cytokeratin and negative for vimentin and EMA.

In conclusion, myoepitheliomas are rare benign tumors arising from minor and major salivary glands. Immunohistochemical staining is extremely important for diagnosis. The clear cell variants of myoepitheliomas are extremely rare on the palate with only one case reported. Adequate excision with clear margins is usually curative.

\section{REFERENCES}

1. Sciubba JJ, Brannon RB. Myoepithelioma of salivary glands: Report of 23 cases. Cancer 1982; 49:280.

2. Neville BW. Oral \& Maxillofacial Pathology. Philadelphia, PA, Saunders, 2001:413.

3. Seifert G. Histological Typing of Salivary Gland Tumors (ed 2). World Health Organization International Histological classification of Tumors. Berlin, Germany,Springer-Vet-lag. 1991;12

4. Kanazawa H, Furuya T, Watanabe T, Kato J. Plasmacytoid myoepithelioma of the palate. $J$ Oral Maxillofac Surg 1999; 57: 857-60.

5. Agarwal AK, Sethi A, Chopra S, Sareen D.

Clear cell myoepithelioma of the hard palate Braz J Oral Sci 2007 ;6(23):1467- 1469.

6. Barnes L, Appel BN, Perez H, El-Attar AM.

Myoepitheliomas of the head and neck: case

report and review. J Surg Oncol 1985; 28: 21-8.

7. De Stefani A, Lerda W, Bussi M, Valente G,

Cortesina $G$. Tumours of the parapharyngeal

space: case report of clear cell myoepitheliom

of the parotid gland and review of literature.

Acta Otolaryngol Ital 1999; 19: 276-82.

8. Maiorano E, Altini M, Favia G. Clear cell tumors of the salivary glands, jaws and oral mucosa. Semin Diagn Pathol 1997; 14: 203-12.
9. Kahn LB, Schoub L. Myoepithelioma of the palate: histochemical and ultrastructural observations. Arch Pathol. 1973; 95:209-211.

10. Luna MA, Mackay B, Games-Araujo J: Myoepithelioma of the palate: Report of a case with histochemical and electron microscopic observation. Cancer 1973; 32:p1429.

11. Nesland JM, Olafsson J, Sobrinho-Simoes M. Plasmacytoid myoepithelioma of the palate. J Oral Pathol. $1981 ; 10: 14-21$

12. Enomoto $T$, Hori $M$, Miyake $M$, et al: So called myoepithelioma of the soft palate: Report of a case. Jpn J Oral Maxillofac Surg 1985; 31: p351.

13. Ellyn JEW, Gnepp DR: Myoepithelioma of the palate in a child. Int $\mathrm{J}$ Pediatr Otorhinolaryngol 1986; 11: p 5 .

14. Kawabe $R$, Masuda G, Horimoto $S$, et al: Plasmacytoid myoepithelioma ofminor salivary gland origin: A case report of the soft palate and review of the literature. Jpn J Oral Maxillofac Surg 1991; 37:p1055

15. Stromeyer FW, Haggitt RC, Nelson JF, et al: Myoepithelioma of minor salivary gland origin: light and electronmicroscopical study. Arch Pathol 1975;99:p242

16. Harusachi K, Takanori F, Toshihide W, J Ora
Maxillofac Surg 1999; 57:p857.

17. Rastogi S, Modi M, Dhawan V, et al. Myoepithelioma of palate. A case report and review of literature. JCDR. 2008; 6:1095-1099.

18. Lins JE, Gnepp DR. Myoepithelioma of the palate in a child. Int J Pediatr Otorhinolaryngol. 1986; $11: 5-13$.

19. Lopez JI, Ugalde A, Arostegui J, Bilbao FJ. Plasmacytoid myoepithelioma of the soft palate. Report of a case with cytologic, immunohistochemical and electron microscopic studies. Acta Cytol. $2000 ; 44$ :647-52.

20. Acikalin MF, Pasaoglu 0, Cakli H, Ciftci E. Plasmacytoid myoepithelioma of the soft palate: a review of the literature and report of a case with immunohistochemical findings. Kulak Burun Bogaz lhtis Derg. 2005; 14:127-30.

21. Zelaya FC, Rivera DQ, Vazquez JLT, et al. Plasmacytoid myoepithelioma of the palate. Report of one case and review of the literature. Med Oral Patol Oral Cir Bucal. 2007;12:552-555.

22. Katsuyama E, Kaneoka A, Higuchi K. Myoepithelioma of the soft palate. Acta Cytol 1997; 41:1856-8.

23. Nwoku AL, Al-Shlash S, Al-Atel A. Pediatric myoepithelioma of the palate. Saudi Med J. 2005; 226:999-1002. 